\title{
Inositol Trisphosphate Receptors in the Vascular Development
}

\author{
Keiko Uchida, Maki Nakazawa, Chihiro Yamagishi, \\ Katsuhiko Mikoshiba, and Hiroyuki Yamagishi
}

\author{
Keywords \\ Intracellular calcium • Vascular development • Angiogenesis • Placenta
}

The placental circulation is crucial for the development of mammalian embryos [1]. The labyrinth layer in the placenta is created by extensive villous branching of the trophoblast and vascularization arising from the embryonic mesoderm. In the labyrinth, materials are exchanged between the maternal and embryonic circulation. Recently, we have found that inositol 1,4,5-trisphosphate $\left(\mathrm{IP}_{3}\right)$ receptors $\left(\mathrm{IP}_{3} \mathrm{Rs}\right)$ may be required for the placental vascularization.

$\mathrm{IP}_{3} \mathrm{Rs}$ are intracellular $\mathrm{Ca}^{2+}$ release channels that have three subtypes in mammals $\left(\mathrm{IP}_{3} \mathrm{R} 1, \mathrm{IP}_{3} \mathrm{R} 2\right.$ and $\left.\mathrm{IP}_{3} \mathrm{R} 3\right)$ [2]. We previously showed that $\mathrm{IP}_{3} \mathrm{R} 1$ and $\mathrm{IP}_{3} \mathrm{R} 2$ played an essential role in heart development from the analysis of mouse embryo double knockout for $\mathrm{IP}_{3} \mathrm{R} 1$ and $\mathrm{IP}_{3} \mathrm{R} 2$ [3]. A previous report on the

\footnotetext{
K. Uchida

Department of Pediatrics, Keio University School of Medicine, 35 Shinanomachi, Shinjuku-ku, Tokyo 160-8582, Japan

Health Center, Keio University, 4-1-1 Hiyoshi, Kohoku-ku, Yokohama, Kanagawa 223-8521, Japan

M. Nakazawa • C. Yamagishi • H. Yamagishi $(\bowtie)$

Department of Pediatrics, Keio University School of Medicine, 35 Shinanomachi, Shinjuku-ku, Tokyo 160-8582, Japan

e-mail: hyamag@keio.jp

K. Mikoshiba
}

Laboratory for Developmental Neurobiology, RIKEN Brain Science Institute, Saitama 351-0198, Japan

Calcium Oscillation Project, International Cooperative Research Project and Solution-Oriented Research for Science and Technology, Japan Science and Technology Agency, Kawaguchi, Saitama 332-0012, Japan

T. Nakanishi et al. (eds.), Etiology and Morphogenesis of Congenital Heart Disease, DOI 10.1007/978-4-431-54628-3_32 


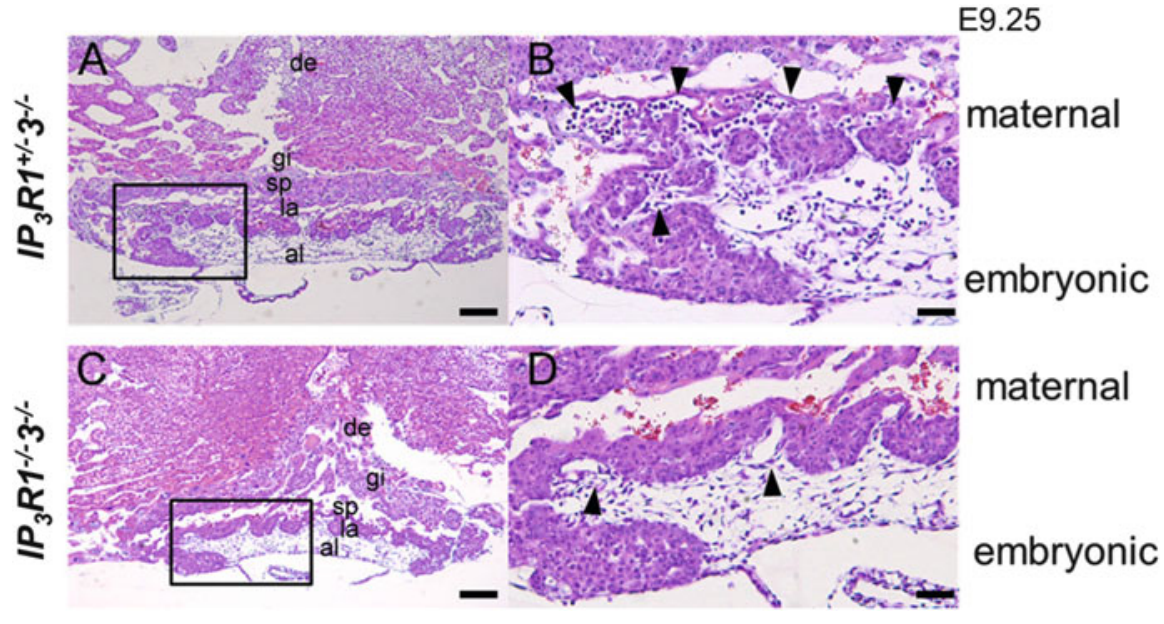

Fig. 32.1 Cross sections of E9.25 placentas from the $\mathrm{IP}_{3} \mathrm{R} 1^{+/-} 3^{-/-}(\mathbf{a}$ and $\mathbf{b})$ and $\mathrm{IP}_{3} \mathrm{R} 1^{-1-} 3^{-1-}$ (c and d) mice. (b) and (d) show higher-power fields of the rectangular areas of the labyrinth in (a) and (c), respectively. Embryonic vessels (arrowheads) fail to elongate to the maternal sinuses in the placenta of $\mathrm{IP}_{3} \mathrm{R}^{-1-} 3^{-1-}$ compared to that of $\mathrm{IP}_{3} \mathrm{R}^{+/-} 3^{-1-}$ (wild type). al allantois, de decidua, gi trophoblast giant cells, la labyrinth layer, $s p$ spongiotrophoblast layer. Scale bars, $0.5 \mathrm{~mm}$ in (a) and (c) and $0.2 \mathrm{~mm}$ in (b) and (d)

requirement for phospholipase (PLC) $\delta 1$ and $\delta 3$ [4] that produce $\mathrm{IP}_{3}$ for placentation led us to investigate the placental defects by deletion of any subtypes of $\mathrm{IP}_{3} \mathrm{Rs}$. Our preliminary result revealed that embryonic vasculature in the labyrinth was impaired in the placenta double knockout for $\mathrm{IP}_{3} \mathrm{R} 1$ and $\mathrm{IP}_{3} \mathrm{R} 3$ at $\mathrm{E} 9.25$ (Fig. 32.1). The detailed phenotype and the underlying mechanism how the intracellular $\mathrm{Ca}^{2+}$ signaling via $\mathrm{IP}_{3} \mathrm{Rs}$ may be implicated in the development of extraembryonic vasculature are under investigation.

This work was supported by a Grant-in-Aid for Scientific Research from the Ministry of Education, Culture, Sports, Science and Technology, Japan (to K.U. and H.Y.).

Open Access This chapter is distributed under the terms of the Creative Commons AttributionNoncommercial 2.5 License (http://creativecommons.org/licenses/by-nc/2.5/) which permits any noncommercial use, distribution, and reproduction in any medium, provided the original author(s) and source are credited.

The images or other third party material in this chapter are included in the work's Creative Commons license, unless indicated otherwise in the credit line; if such material is not included in the work's Creative Commons license and the respective action is not permitted by statutory regulation, users will need to obtain permission from the license holder to duplicate, adapt or reproduce the material. 


\section{References}

1. Rossant J, Cross JC. Placental development: lessons from mouse mutants. Nat Rev Genet. 2001;2:538-48.

2. Berridge MJ, Lipp P, Bootman MD. The versatility and universality of calcium signalling. Nat Rev Mol Cell Biol. 2000;1:11-21.

3. Uchida K, Aramaki M, Nakazawa M, Yamagishi C, Makino S, et al. Gene knock-outs of inositol 1,4,5-trisphosphate receptors types 1 and 2 result in perturbation of cardiogenesis. PLoS One. 2010;5:e12500.

4. Nakamura Y, Hamada Y, Fujiwara T, Enomoto H, Hiroe T, et al. Phospholipase C-delta1 and -delta3 are essential in the trophoblast for placental development. Mol Cell Biol. 2005;25:10979-88. 